\title{
Environmental Impact of Mining Exploitation: A Case Study of Some Mines of Barite in the Eastern Anti-Atlas of Morocco
}

\author{
Abdelhafid Essalhi, Mourad Essalhi, Abdeslam Toummite \\ Equipe de Recherche: Géophysique, Géoressources et Patrimoine (ER-GGP), Département de Géologie, \\ Faculté des Sciences et Techniques, Errachidia, Maroc \\ Email: mourad.essalhi@gmail.com
}

How to cite this paper: Essalhi, A., Essalhi, M. and Toummite, A. (2016) Environmental Impact of Mining Exploitation: A Case Study of Some Mines of Barite in the Eastern Anti-Atlas of Morocco. Journal of Environmental Protection, 7, 1473-1482. http://dx.doi.org/10.4236/jep.2016.711124

Received: July 30, 2016

Accepted: October 10, 2016

Published: October 13, 2016

Copyright $\odot 2016$ by authors and Scientific Research Publishing Inc. This work is licensed under the Creative Commons Attribution International License (CC BY 4.0).

http://creativecommons.org/licenses/by/4.0/ (c) (i) Open Access

\begin{abstract}
Extraction of mineral resources is the backbone of the national economy in many developed and developing countries of the world. However, the exploitation can have many negative impacts on the immediate environment of the exploitation sites. In this study performed on some mining areas of the Moroccan Anti-Atlas, four principal negative effects were detected: effect on the physiognomy, on safety, on health, and on recovery rate. The principal source of this situation is the exploitation of the ore deposits from top to bottom without using any geological preparation and the use of non-adapted exploitation technics. To minimize these impacts, we propose to establish a geological study and advanced mining exploration before starting exploitation, and follow an exploitation technic well adapted to the morphology of the ore deposit like cut-and-fill mining and sublevel stoping methods.
\end{abstract}

\section{Keywords}

Negative Impacts, Environment, Exploitation, Physiognomy, Anti-Atlas

\section{Introduction}

In the last times, the world had experienced several and rapid changes in population habits and it knew more technological innovations. These technological changes occur with a great and increasing speed. Human development is accompanied with increasing 
demands for minerals, construction materials and energy, which explains the increase in natural resource exploitation worldwide.

Construction materials and mineral resources constitute an important source of wealth for a nation. However, their exploitation product has different types of environmental damage [1]-[5].

In Morocco, exploitation of mineral resources is done everywhere, especially in the High Atlas and the Anti-Atlas. It is of precious metals $(\mathrm{Au}, \mathrm{Ag}, \ldots)$, base metals $(\mathrm{Cu}, \mathrm{Zn}$, $\mathrm{Pb}, \ldots$ ), and industrial minerals (barite, fluorite,...). In this paper, we interest to barite exploitation in the Eastern Anti-Atlas. We will talk about the current situation, the effect of mineral resources exploitation on the environment, and discuss some solutions to minimize the influence of this on the environment.

The Eastern Anti-Atlas knows a very important mining activity favored by the abundance of barite vein deposits. In a large part of the Eastern Anti-Atlas, exploitation of barite, lead and zinc ores is managed by a Central Regional Development Commission (or CADETAF for Centrale d'Achat et de Développement de la région minière de Tafilalet et de Figuig). This governmental agency offers a wide range of services to artisanal miners extracting high-grade barite, lead and zinc ore in studied area. Also, it operates seven regional ore purchasing centers that provide basic materials and essential services to miners. Thus, CADETAF gives small operating permissions to Artisanal miners (100 m), which promotes the artisanal exploitation in a lot part of the Eastern Anti-Atlas Mountains.

During the past three decades, this region has seen a big proliferation of artisanal mining of the barite ore. The main reason for this propagation is the fact that the marketing of this substance does not require expensive pre-treatment, because the majority of administrative procedures are performed by the CADETAF. Therefore, many ore sills have exploited and still incur severe and anarchic exploitation, but artisanal miners use very traditional way, which does not use professional technical operation that can preserve the environment and optimize the exploitation of ore bodies. All that inevitably involves direct or indirect damages to the environment. So, exploitations of the Eastern Anti-Atlas affect the immediate environment by the deformation of its natural appearance.

\section{Overview of the Barite's Exploitation in the Eastern Anti-Atlas}

As mentioned in the introduction, we focus here only on mining operations concerning some ore deposits of barite in the Eastern Anti-Atlas. We chose then following mining areas: 1) Ras Kammouna, 2) Tijjekht, 3) Boumaiz, 4) Chaib-Ras, 5) Bouizrane 6) M'fis and 7) Njakh.

\subsection{Studied Mining Areas}

\section{1) The Ras Kammouna mining area}

This mining area is located in the south of Jbel Issimour, $66 \mathrm{~km} \mathrm{SSW}$ of Rissani city, on the southern limb of the Ougnat inlier (coordinates: $30.70^{\circ} \mathrm{N} 4.50^{\circ} \mathrm{W}$ ) (Figure 1). $30^{\circ}, 90^{\circ}$ oriented veins that carry mineralization, principally of barite, are enclosed in late Ordovician sandstones. The artisanal miners use trenches to extract barite (Figure 1 and Table 1). 

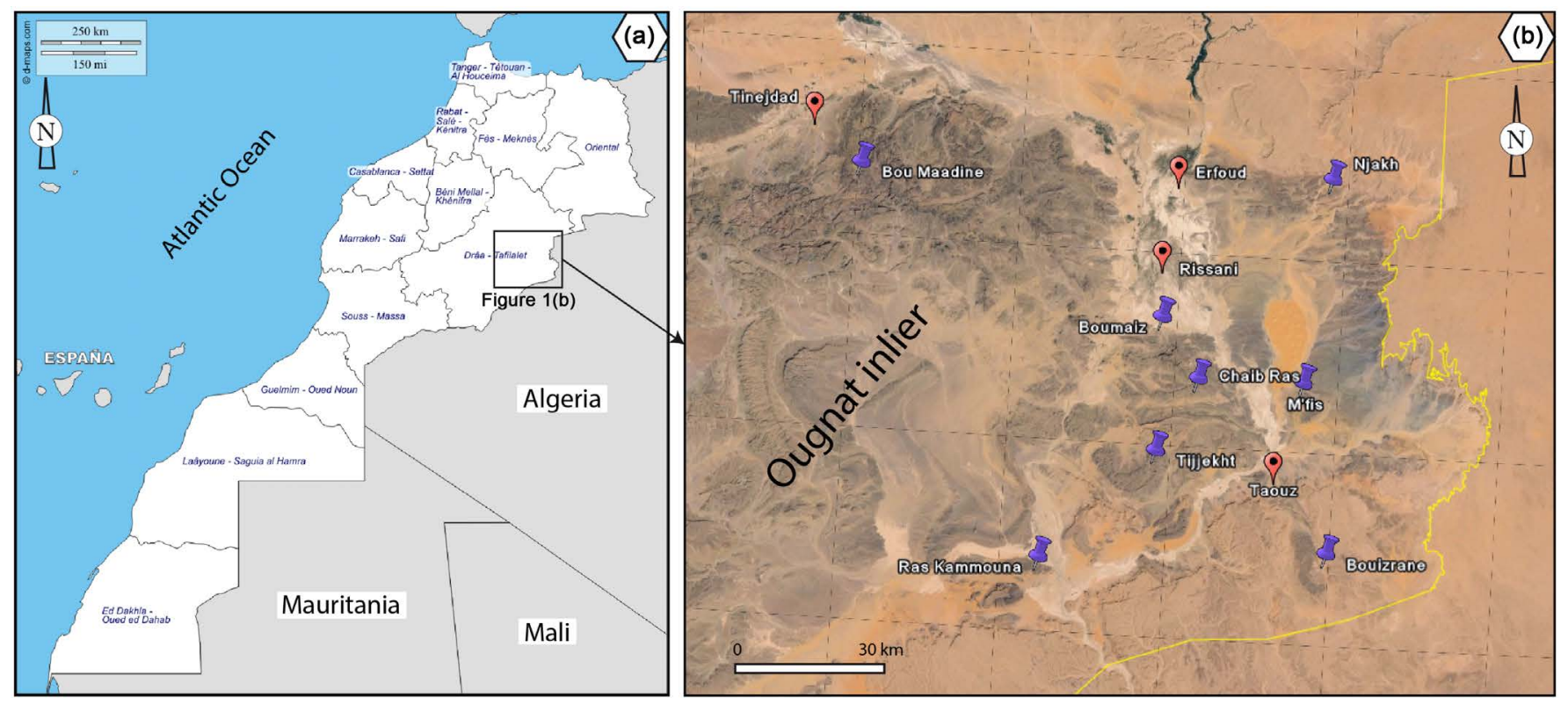

Figure 1. Geographic situation of studied areas. (a): geographic map of Morocco and (b): zoom in on the eastern part of the Ougnat inlier, which contain studied mines.

Table 1. General characteristics of studied ore deposits.

\begin{tabular}{|c|c|c|c|c|c|c|c|c|c|c|}
\hline Mining area & $\begin{array}{c}\text { GPS } \\
\text { coordinates }\end{array}$ & $\begin{array}{c}\text { Geometry } \\
\text { of the ore } \\
\text { deposit }\end{array}$ & $\begin{array}{l}\text { Orientation of } \\
\text { the ore deposit }\end{array}$ & Surrounding rock & $\begin{array}{l}\text { Age of } \\
\text { surrounding } \\
\text { rock }\end{array}$ & Mineralization & $\begin{array}{l}\text { Exploitation } \\
\text { method }\end{array}$ & $\begin{array}{l}\text { Length } \\
(\mathrm{m})\end{array}$ & $\begin{array}{l}\text { Max. } \\
\text { depth } \\
(\mathrm{m})\end{array}$ & $\begin{array}{c}\text { Max. } \\
\text { opening } \\
(\mathrm{m})\end{array}$ \\
\hline Ras Kammouna & $30.70^{\circ} \mathrm{N}$ & Vein-type & $\mathrm{N} 30^{\circ}, 90^{\circ}$ & Sandstone & $\begin{array}{c}\text { Late } \\
\text { Ordovician }\end{array}$ & Barite & Trenches & 500 & 45 & 3 \\
\hline Tijjekht & $30.90^{\circ} \mathrm{N}$ & Vein-type & $\mathrm{N} 100^{\circ}, 80 \mathrm{~N}^{\circ}$ & Sandstone & $\begin{array}{c}\text { Middle } \\
\text { Cambrian }\end{array}$ & Barite & $\begin{array}{c}\text { Trenches, } \\
\text { wells, galeries }\end{array}$ & 1500 & 70 & 4 \\
\hline Boumaiz & $31.15^{\circ} \mathrm{N}$ & Vein-type & $\mathrm{N} 55^{\circ}, 90^{\circ}$ & $\begin{array}{c}\text { Alternation of } \\
\text { sandstone and } \\
\text { shale }\end{array}$ & Late Ordovician & Barite & Trenches & $* * *$ & 130 & $* * *$ \\
\hline Chaib Ras & $31.04^{\circ} \mathrm{N}$ & Vein-type & $\mathrm{N} 35^{\circ}, 90^{\circ}$ & Sandstone & Late Ordovician & Barite & Trenches and wells & 1600 & 60 & 4 \\
\hline $\begin{array}{l}\text { Bouizrane } \\
\text { (Jbel zorg) }\end{array}$ & $30.73^{\circ} \mathrm{N}$ & Vein-type & $\mathrm{N} 70^{\circ}, 75 \mathrm{~N}^{\circ}$ & $\begin{array}{c}\text { Alternation of } \\
\text { sandstone and } \\
\text { shale }\end{array}$ & $\begin{array}{c}\text { Middle } \\
\text { Cambrian }\end{array}$ & Barite & Trenches and wells & 300 & 50 & 5 \\
\hline M'fis & $31.04^{\circ} \mathrm{N}$ & Vein-type & $\mathrm{N} 100^{\circ}, 60 \mathrm{~N}^{\circ}$ & $\begin{array}{l}\text { Sandy shale, } \\
\text { carbonates } \\
\text { and } \\
\text { magmatic rocks }\end{array}$ & Late Devonian & $\begin{array}{c}\text { alquifoux } \\
\text { (compact } \\
\text { galena), pyrite, } \\
\text { chalcopyrite, } \\
\text { barite, goethite, } \\
\text { pyrolusite }\end{array}$ & Trenches & 2000 & 60 & 3 \\
\hline Njakh & $31.41^{\circ} \mathrm{N}$ & Vein-type & $\mathrm{N} 45^{\circ}, 90^{\circ}$ & $\begin{array}{c}\text { Green } \\
\text { sandstone } \\
\text { and siltites }\end{array}$ & $\begin{array}{c}\text { Middle } \\
\text { Cambrian to } \\
\text { Late } \\
\text { Ordovician }\end{array}$ & $\begin{array}{c}\text { Barite } \\
\text { (Fluorite) }\end{array}$ & $\begin{array}{l}\text { Trenches } \\
\text { and wells }\end{array}$ & 400 & 40 & 8 \\
\hline
\end{tabular}

\section{2) The Tijjekht mining area}

The Tijjekht mining area is located at $24 \mathrm{~km}$ western of Taouz city and $32 \mathrm{~km}$ northeastern of the Ras Kemmouna mining area (GPS coordinates: $30.90^{\circ} \mathrm{N}, 4.26^{\circ} \mathrm{W}$ ) (Figure 1). Exploited for barite, the ore sills of Tijjekht are enclosed in Middle Cambrian sand- 
stone. The global orientation of ore deposits is $\mathrm{N} 100^{\circ}, 80^{\circ} \mathrm{N}$. The artisanal miners extract barite ore of barite using trenches, wells and galleries (Figure 1 and Table 1).

3) The Boumaiz mining area

Close to Rissani City (12 km southern of), the ore sills of this mining area are enclosed in Late Ordovician alternation of shale and sandstone layers (GPS coordinates: $31.15^{\circ} \mathrm{N}, 4.26^{\circ} \mathrm{W}$ ) (Figure 1). The trenches technic is the main method used to extract ore deposit from $\mathrm{N} 55^{\circ}, 90^{\circ}$ ore sills (Figure 1 and Table 1 ).

4) The Chaib-Ras mining area

The Chaib-Ras mining area is situated at $17 \mathrm{~km}$ southern Rissani city and $15 \mathrm{~km}$ northwestern Taouz city (GPS coordinates: $31.04^{\circ} \mathrm{N}, 4.18^{\circ} \mathrm{W}$ ) (Figure 1). The mineralization is enclosed in Late Ordovician sandstone. Like previous ore deposits, this one is exploited for barite in ore sills oriented $\mathrm{N} 90^{\circ}, 90^{\circ}$. Trenches and wells are used to extract barite (Figure 1 and Table 1).

5) The Bouizrane mining area

At $12 \mathrm{~km}$ southeastern of the Touz city, the $\mathrm{N} 70^{\circ}, 75^{\circ} \mathrm{N}$ ore sills of Bouizrane are enclosed in Middle Cambrian alternation of shale and sandstone layers (GPS coordinates: $30.73^{\circ} \mathrm{N}, 3.88^{\circ} \mathrm{W}$ ) (Figure 1). The barite ore is exploited by using trenches and wells (Figure 1 and Table 1).

6) The $M$ fis mining area

The M'fis mining area is a big polymetallic deposit that is rich by galena, pyrite, chalcopyrite, barite, goethite and pyrolusite. Geographically, the main mine of M'fis is situated at $11 \mathrm{~km}$ northern of Taouz city and $14 \mathrm{~km}$ the eastern of Chaib-Ras mining area $\left(31.04^{\circ} \mathrm{N}, 3.95^{\circ} \mathrm{W}\right.$ ) (Figure 1 ). $\mathrm{N} 100^{\circ}, 60^{\circ} \mathrm{N}$ ore sills polymetallic mineralization are enclosed in sandy shales, carbonates and magmatic rocks of the late Devonian. All mining works are doing by trenches (Figure 1 and Table 1 ).

7) The Njakh mining area

The last studied mining area is the Njakh mine (GPS coordinates: $31.41^{\circ} \mathrm{N}, 3.91^{\circ} \mathrm{W}$ ). $30 \mathrm{~km}$ at the east of Erfoud city, the mineralization is mainly barite with small amounts of fluorite. Like all deposit cited above, barite (fluorite) mineralization is mainly as veins with $\mathrm{N} 45^{\circ}, 90^{\circ}$ orientation. The surrounding rocks are mainly green sandstone and siltites of the Middle Cambrian to Late Ordovician. Artisanal miners use trenches to exploit the ore deposit (Figure 1 and Table 1).

\subsection{Geological Studies before Starting Exploitation}

Before starting a mining exploitation, a number of steps will be done. Therefore, geologist will follow some steps to have a good knowledge of the future exploited ore. After [6], when a prospect has been identified, assessing it involves advancing through a progressive series of definable exploration stages. Positive results in any stage will lead to advance to the next stage and an escalation of the exploration effort. Negative results mean that the prospect will be discarded, sold or joint ventured to another party, or simply put on hold until the acquisition of fresh information/ideas/technology leads to its being reactivated. Thus, prospect exploration will generally go through four stages 
[6]; i) target generation: this includes all exploration on the prospect undertaken prior to the drilling of holes directly targeted on potential ore; ii) target drilling: This stage is aimed at achieving an intersection of ore, or potential ore. The testing will usually be by means of carefully targeted diamond or rotary-percussion drill holes, but more rarely trenching, pitting, sinking a shaft or driving an adit may be employed; iii) resource evaluation drilling: This stage provides answers to economic questions relating to the grade, tones and mining/metallurgical characteristics of the potential ore body. Finally, iv) feasibility study which the final stage in the process, is a desktop due-diligence study that assesses all factors-geological, mining, environmental, political, economic_relevant to the decision to mine.

All cited steps are required to have a good idea on all characteristics of the ore deposit: geometry of the mineralized bodies, depth, grade, tonnage, risks related to mining operations, profitability...

Although it must respect these steps to better manage mining operations, we noticed that the Artisanal miners who operate the different studied deposits start operation without any prior geological study. They consider only the visible part of the ore without having any idea on the rooting of the exploited veins. The worst is that there is no geologist in all visited sites, and then artisanal miners operate without intervention or monitoring geologist. That pushes them to stop exploiting soon as mineralization stops. They start exploitation from the surface to the depth and leave security stocks with the progress of mining works.

\subsection{Method of Exploitation}

Before starting any operation of exploitation, it is necessary to choose the most suitable method. So, the mining method selected for exploitation is determined mainly by the characteristics of the mineral deposit and the limits imposed by safety, technology, environmental concerns, and economics. Geologic conditions, such as the dip, shape and strength of the ore and the surrounding rock, play a key role in selecting the method. Traditional exploitation methods fall into two broad categories: surface or underground. Surface mining includes mechanical excavation methods such as open pit and open cast (strip mining), and aqueous methods such as placer and solution mining. Underground mining is usually classified in three categories of methods: unsupported, supported, and caving.

Surface mining is the predominant exploitation procedure worldwide, whereas Underground methods less used. These later (unsupported, supported, and caving) are differentiated by the type of wall and roof supports used, the configuration and size of production openings, and the direction in which mining operations progress.

Although the start of exploitation of any deposit is conditioned by preliminary geological and technical studies, mining exploitation in studied ore deposits is done with a unique method; the artisanal miners start exploitation from the top to the bottom of veins. They only follow the visible mineralization vertically and laterally. As mentioned in the Table 1, the ore bodies are filonian mineralization with strong dip and compe- 
tent surrounding rock. This configuration is more suitable for underground exploitation, spatially the cut-and-fill mining. This method has the advantage to be safer and to provide a good recovery rate.

\section{Some Examples of Negative Impacts of Barite Exploitation}

Usually, the mining operation have a lot environment and social of impacts (affects air, soil, water, fauna and flora, Acid Mine Drainage, noise and vibration, migration of population from/or to the mining areas, ...). However, in this work, we focus on the impact of studied mining operations on the landscape physiognomy, the safety of population, the recovery rate and the health.

The method of exploitation used by artisanal miners in the region is archaic. They start the mining operations without any geological or technical studies. The exploitation began always from the top to the bottom of the filonian ore bodies, and they continue laterally and vertically without having a clear idea about their characteristics (geometry, power, grade, tonnage, ...).

This situation has many negative consequences on the environment like:

On the physiognomy: since studied mineralization is exclusively filonian, and since its exploitation is done from top to bottom, this type of mining operations leads to the development of long, broad and deep trenches that disfigure the general landscape of the region (Figure 2). These trenches appear as large tears in mining sites. The proof is that they are clearly visible on satellite images and on Google Earth (Figure 3). Progressively as the operation progresses, trenches are increasingly deep and long.

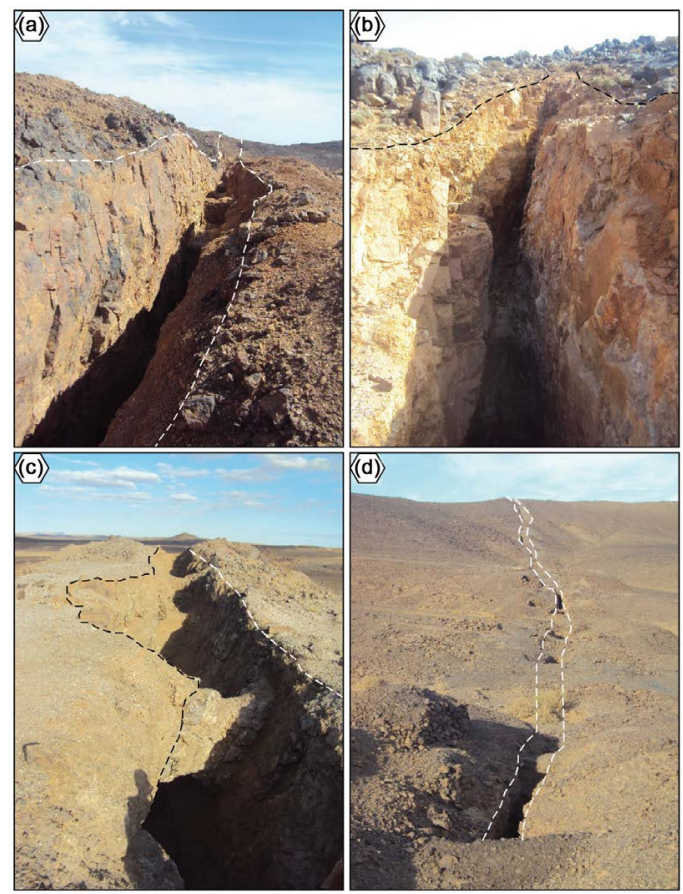

Figure 2. Effect of barite exploitation on the physiognomy of different sites. (a): Chaib-Ras; (b): Tijjekht; (c): M’Fis; (d): Boumaiz. 

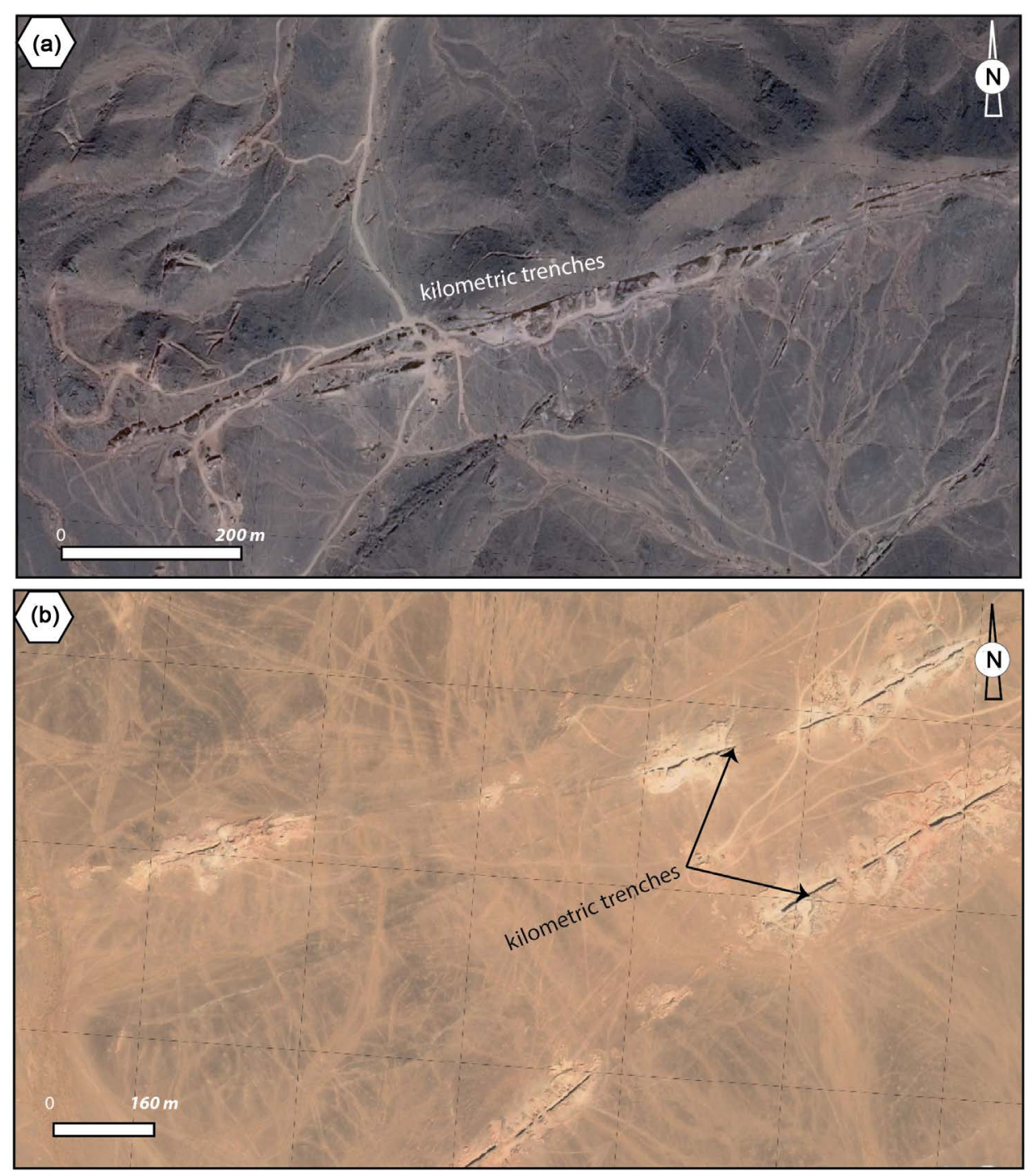

Figure 3. Effect of barite exploitation on the physiognomy of different sites. Long trenches observed on Google Earth. (a): Chaib-Ras; (b): Bouizrane.

On safety: the deep trenches left by artisanal exploitation constitute a real danger to the lives of local residents and animals of the area. This risk is important during mining operations and after the abandonment of the mine site (Figure 4(a) and Figure 4(b)).

On recovery rate: one of the main commitments of the mining operators before starting a mine is to ensure the maximum exploitation of the deposit, i.e. to achieve a maximum of deposit recovery rate, and to leave only what is technically impossible to exploit. Unfortunately, the method used in the studied areas does not allow honoring this commitment. The non-geological and technical preparation does not have a prior idea about the properties of the deposit. In addition, the used archaic method of exploitation is based on monitoring the observable part of the deposit. These technical and economic factors lead to massacre of the deposit by abandoning a lot of economic mineralization (Figure 4(c) and Figure 4(d)).

On health: The artisanal exploitation of barite in the studied areas have can also 

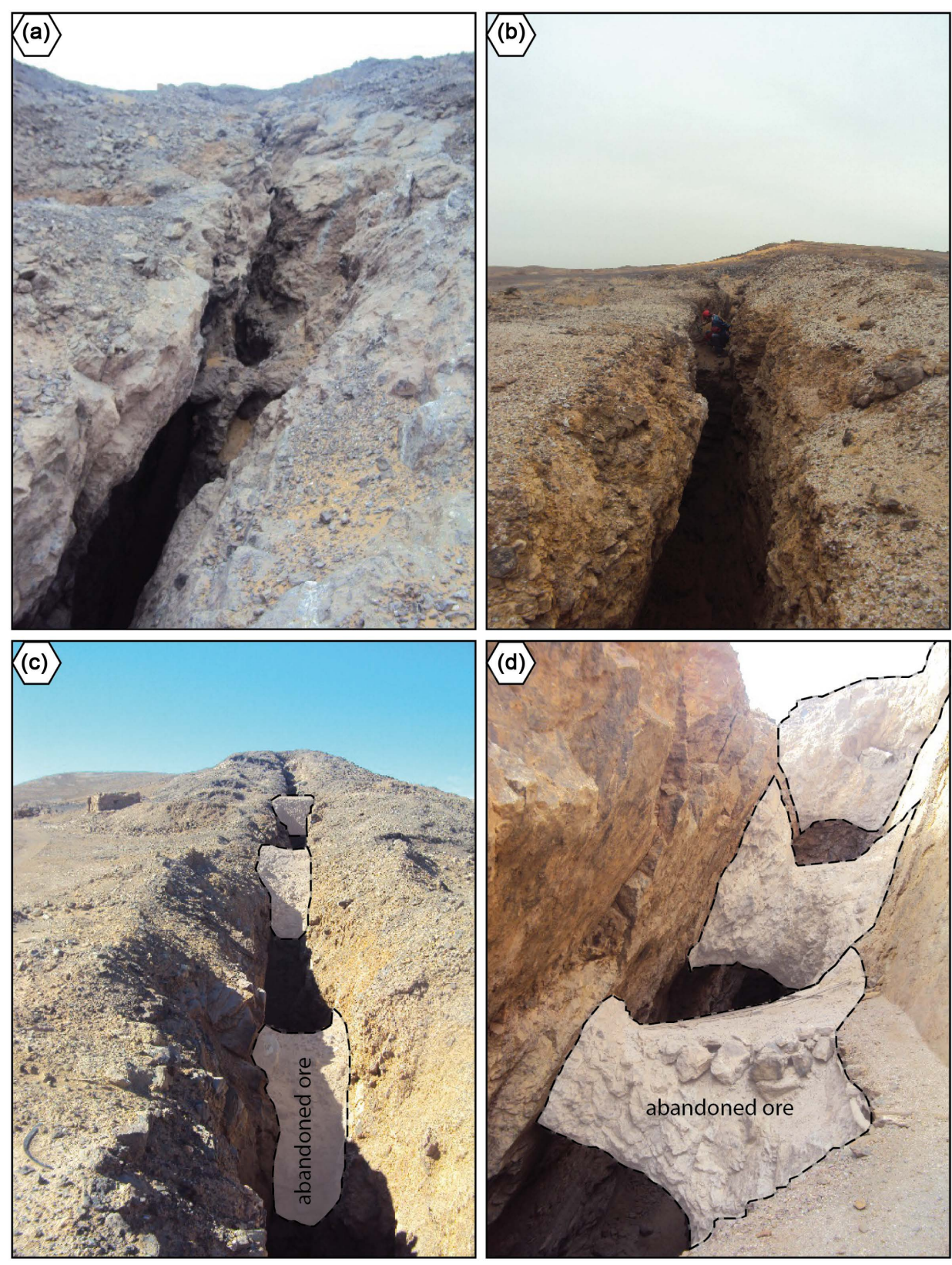

Figure 4. Effect of barite exploitation on the safety ((a) and (b)), and rate recovery ((c) and (d)) of different sites. (a) and (b): M’Fis; (c): Boumaiz; (d): Chaib-Ras.

cause same health damages to workers and residents of mining areas. Therefore, large volume of dust from the mining operations is discharged daily into the air. When the air is laden with such dust, it causes health hazards for some people. In addition, the noise generated during drilling, blasting, quarrying and crushing can also cause health problems of the miners and frighten away part of the fauna in a mining locality.

\section{Some Proposals to Limit the Negative Effects}

It is obvious that the negative impacts of barite exploitation in studied areas are mainly 
due to poor preparation of the mine. The lack of geological exploration makes unacknowledged the deposits, and thus makes impossible their exploitation with respect to the international standards. In addition, the inadequate exploitation method obliges artisanal miners to exploits only the visible parts of the deposits. Therefore, both nongeological exploration and non-adequate exploitation method cause the previously mentioned negative impacts. Consequently, to eliminate these negative impacts or at least to minimize their effects, it is recommended that:

Establish a geological study and advanced mining exploration at the deposits to be exploited future, to evaluate their mining potential before start of exploitation. This will facilitate the choice of the exploitation method, better start mining operations, and ensure good ore recovery rate.

Follow an exploitation technic well adapted to the morphology of the ore deposit. The chosen method must consider the different geometric and geotechnical parameters of the mineralization. Since the majority of deposits are filonian with high dip and competent surrounding rock, it is recommended to use the method of cut-and-fill mining and sublevel stoping. It will allow a good ore recovery rate and avoid having long and deep trenches that alter the appearance of the area. Cut-and-fill mining is suitable for a steeply dipping mineral deposit contained in a rock mass with good to moderate stability. It removes the ore in horizontal slices starting from a bottom cut and advances upwards, allowing the stop boundaries to be adjusted to follow irregular mineralization. Sublevel stoping (SLOS) is used for mining mineral deposits with: steep dip where the footwall inclination exceeds the angle of repose; stable rock in both hanging wall and footwall; competent ore and host rock; and regular ore boundaries. SLOS recovers the ore in large open stopes, which are normally backfilled to enable recovery of pillars. The orebody is divided into separates topes, between which ore sections are set aside for pillars to support the roof and the hanging wall. Pillars are normally shaped as vertical beams, across the ore body. Horizontal sections of ore are also left as crown pillars (Figure 5) [7]. These conditions correspond perfectly to that of the studied mines.

Rehabilitate mining sites at the end of their life. The authorities should require operator rehabilitating abandoned sites for example by making a fence around the mine. It is also possible to transform the old mines to geoparks by their rehabilitation, thereafter; they can be open to tourists.

\section{Conclusion}

Barite exploitation in the Paleozoic formations of the Ougnat inlier (Anti-Atlas, Morocco) has caused considerable and often irreversible changes in the natural environment. Four principal effects have been observed: the effect on physiognomy, on safety, on health, and on recovery rate. These negative effects have two principal causes: i) the exploitation is always done from top to bottom, whatever the geometry of the ore body, by using archaic exploitation methods. These ones do not take into account the shape of the mineralization. ii) The artisanal miners don't use any geological prospection 

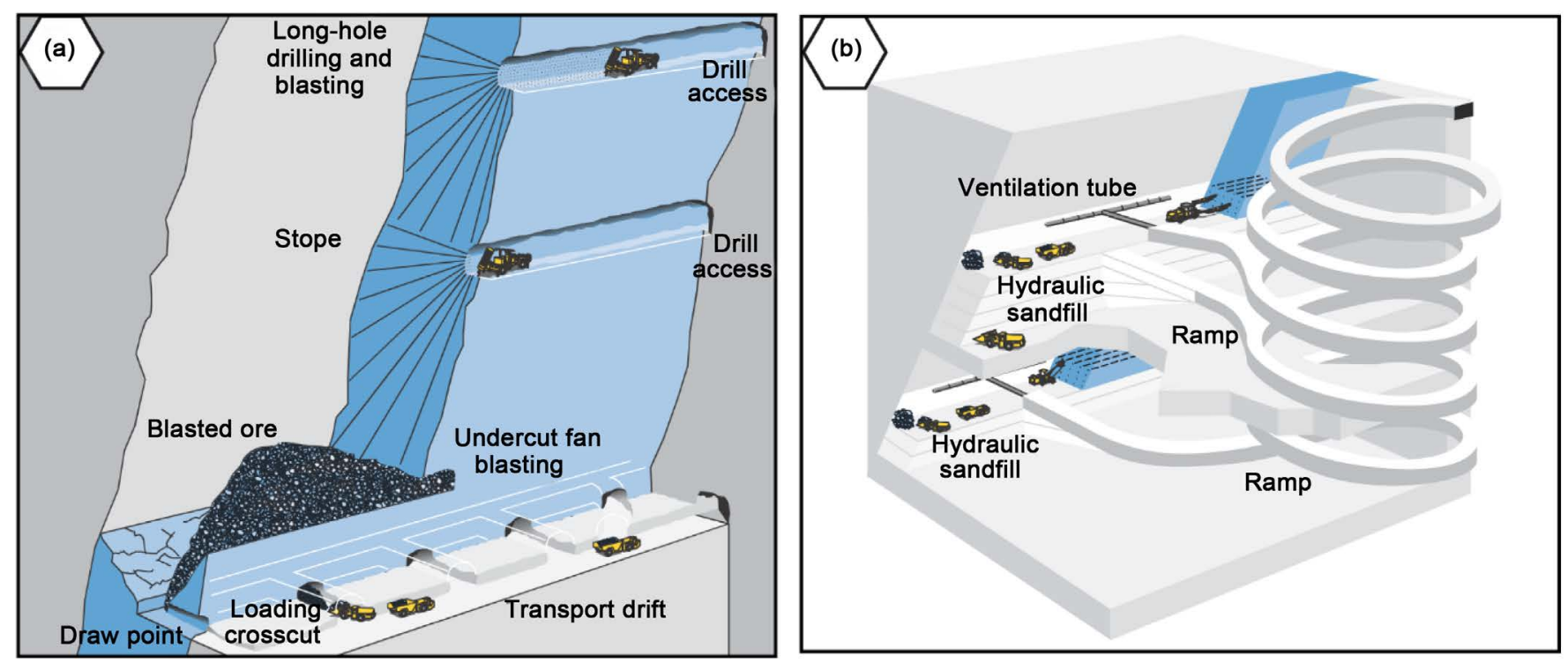

Figure 5. Two underground exploitation methods adapted to redressed ore deposits. (a): Sublevel open stoping layout and (b): cut-andfill stop layout [7].

method to well understand the characteristics of the ore bodies (geometry, depth, grade, tonnage,...). To avoid these negative effects of barite exploitation on environment, it is recommended to i) establish a geological study and advanced mining exploration at the deposits to evaluate their mining potential before start of exploitation; ii) follow an exploitation technic well adapted to the morphology of the ore deposit like cut-and-fill mining and sublevel stoping methods.

\section{References}

[1] Hilson, G. (2002) Small-Scale Mining in Africa: Tackling Pressing Environmental Problems with Improved Strategy. The Journal of Environment \& Development, 11, 149-174. http://dx.doi.org/10.1177/10796502011002003

[2] Cabala, J.M., Cmiel, S.R. and Idziak, A.F. (2004) Environmental Impact of Mining Activity in the Upper Silesian Coal Basin (Poland). Geologica Belgica, 7, 225-229.

[3] Martinec, P. and Schejbalova, B. (2004) History and Environmental Impact of Mining in the Ostrava-Karvina Coal Field (Upper Silesian Coal Basin, Czech Republic). Geologica Belgica, 7, 215-223.

[4] Gutti, B., Aji, M.M. and Magaji, G. (2012) Environmental Impact of Natural Resources Exploitation in Nigeria and the Way Forward. Journal of Applied Technology in Environmental Sanitation, 2, 95-102.

[5] Budnuka, A.C., Clinton, A. and Agi-Ottoh, C. (2015) The Effect of Unplanned Exploitation of Environmental Resources: The Nigeria's Experience. Journal of Environment Pollution and Human Health, 3, 39-45.

[6] Marjoribanks, R. (2010) Prospecting and the Exploration Process. In: Geological Methods in Mineral Exploration and Mining, Springer, Berlin Heidelberg, 1-12. http://dx.doi.org/10.1007/978-3-540-74375-0_1

[7] Copco, A. (2007) Mining Methods in Underground Mining. 2nd Edition, Atlas Copco, Sweden. 
Submit or recommend next manuscript to SCIRP and we will provide best service for you:

Accepting pre-submission inquiries through Email, Facebook, LinkedIn, Twitter, etc. A wide selection of journals (inclusive of 9 subjects, more than 200 journals)

Providing 24-hour high-quality service

User-friendly online submission system

Fair and swift peer-review system

Efficient typesetting and proofreading procedure

Display of the result of downloads and visits, as well as the number of cited articles

Maximum dissemination of your research work

Submit your manuscript at: http://papersubmission.scirp.org/

Or contact jep@scirp.org 